\title{
Linkage of the Multiple Endocrine Neoplasia Type 2B Gene (MEN2B) to Chromosome 10 Markers Linked to MEN2A
}

\author{
ROBERT A. NORUM, ${ }^{*}, 1$ RONALD G. LAFRENIERE, $\dagger$ LAWRENCE W. O'NEAL, $\ddagger$ THOMAS F. NIKOLAI, $\S$

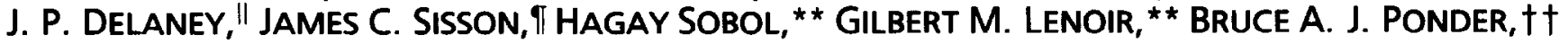 \\ HUNTINGTON F. WILLARD, † AND CHARLES E. JACKSON* \\ *Clinical and Molecular Genetics Division, Department of Medicine, Henry Ford Hospital, Detroit, Michigan 48202; †Department \\ of Genetics, Stanford University, Stanford, California; $¥$ Department of Surgery, St. John’s Mercy Medical Center, St. Louis, \\ Missouri; §Section of Endocrinology, Department of Medicine, Marshfield Clinic, Marshfield, Wisconsin; "Department of Surgery, \\ University of Minnesota Hospitals, Minneapolis, Minnesota; IDivision of Nuclear Medicine, University of Michigan Medical \\ Center, Ann Arbor, Michigan; **International Agency for Research on Cancer, Lyon, France; and ttCRC Human \\ Cancer Genetics Research Group, University of Cambridge, Cambridge, England
}

Received March 23, 1990; revised June 14, 1990

The syndrome of multiple endocrine neoplasia type $2 B$ (MEN 2B) resembles that of MEN 2A in that both include medullary carcinoma of the thyroid, pheochromocytoma, and autosomal dominant inheritance, but is distinct in that MEN 2B patients have neuromas of the mucous membranes. MEN2A has been linked to RBP3, D10S5, FNRB, D10S15, and D10Z1 near the centromere of chromosome 10. We examined linkage between MEN2B and RFLPs on chromosome 10 in all available members in two or three generations of 14 kindreds. The centromere marker D10Z1 was linked to MEN2B with a peak lod score of 5.42 at $\theta=0.02$. One possible recombinant $w$ as observed between D10Z1 and MEN2B. Multipoint analysis of RFLPs at FNRB, D10Z1, RBP3, and D10S15 gave a peak lod score of 7.12 at the midpoint between D10Z1 and RBP3 on the long arm (band q11). The most likely gene order FNRB-D10Z1-MEN2B was 27 times more likely than MEN2B-FNRB-D10Z1 and $3 \frac{1}{2}$ times more likely than FNRB-MEN2B-D10Z1. Additional data will be required to establish the order of these loci with confidence. (c) 1990 Academic Press, Inc.

\section{INTRODUCTION}

Multiple endocrine neoplasia type 2B (MEN 2B) is a syndrome of medullary carcinoma of the thyroid gland (MTC), tumors of the medulla of the adrenal gland, and neuromas of the oral mucosa and is inherited as an autosomal dominant trait. The gene for a similar syndrome of multiple endocrine neoplasia, type 2A (MEN 2A), has been located in the pericentromeric area of chromosome 10 by linkage to several

\footnotetext{
${ }^{1}$ To whom correspondence should be addressed.
}

restriction fragment length polymorphisms (RFLPs) (Mathew et al., 1987; Simpson et al., 1987; Sobol et al., 1988, 1989a; Nakamura et al., 1989; Yamamoto et al., 1989; Wu et al., 1990). MEN $2 B$ is distinguished from MEN 2A by the presence in MEN 2B of the mucosal neuromas, earlier onset and faster growth of the thyroid cancers, and often skeletal abnormalities including the Marfanoid habitus with arachnodactyly (Williams and Pollack, 1966; Gorlin and Mirkin, 1972; Khairi et al., 1975; Carney et al., 1976; Jones and Sisson, 1983; Jackson et al., 1984).

We have reported initial linkage studies with MEN2B (Jackson et al., 1988) that were suggestive of linkage to the centromere marker D10Z1 (lod score of 2.68 at $\theta=0$ ), although only limited data on linkage to the same markers to which MEN2A had been linked were available then. No other reports of linkage analysis of MEN2B have appeared. To test whether genes causing MEN 2A and MEN 2B might be in the same area of the genome, we have examined linkage of MEN2B to RFLPs that have been linked to MEN2A.

\section{MATERIALS AND METHODS}

\section{Families}

Fourteen kindreds with MEN 2B were examined (Fig. 1). Each of the 44 affected individuals in these kindreds had the bumpy lips and/or tongue typical of the oral mucosal neuromas seen in MEN 2B (Williams and Pollock, 1966; Gorlin and Mirkin, 1972; Khairi et al., 1975; Carney et al., 1976). Each had had proven medullary thyroid cancer except for two obviously affected individuals: a newborn girl in pedigree 4 with bumpy lips and feeding difficulties, and a man 

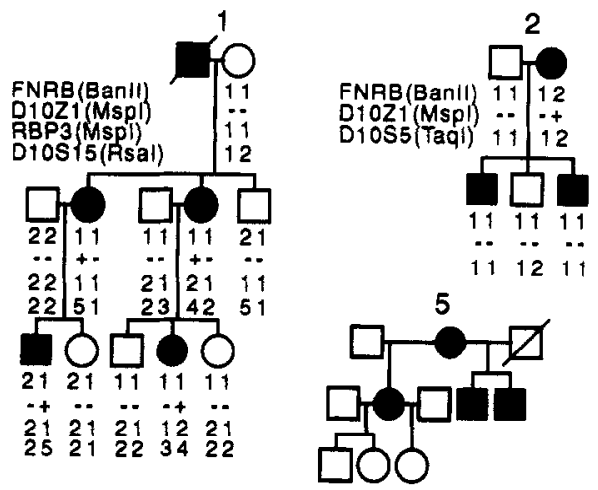

3

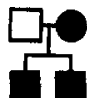

4
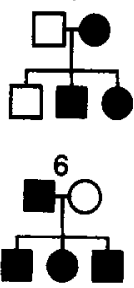

7
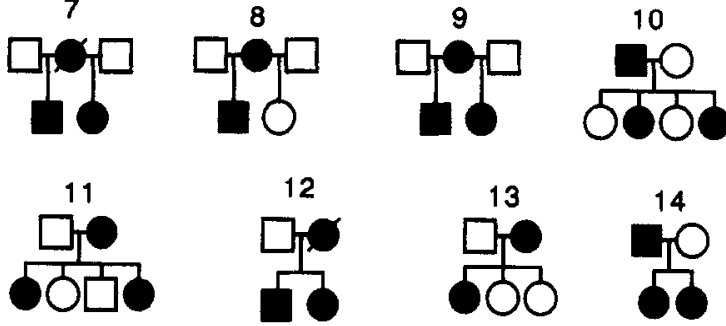

FIG. 1. Abbreviated pedigrees of the 14 MEN $2 B$ families studied. Solid circles and squares indicate affected individuals. DNA was not available from decreased individuals in families $1,5,7$, and 12 indicated by the slashed lines through the symbol, from the youngest unaffected child in family 13 , or from an unaffected spouse in families $8,9,11,13$, and 14. All others were typed for some or all of the polymorphisms.

in pedigree 10 who had refused surgery for his thyroid enlargement although pheochromocytomas had been removed. Nineteen of the 44 had pheochromocytomas and/or adrenal medullary hyperplasia. Pedigree 1 (O'Neal, 1983), pedigree 5 (Khairi et al., 1975), pedigree 8 (Eyer et al., 1988), pedigree 11 (Sobol et al., $1989 \mathrm{~b}$ ), and pedigree 13 (Kullberg and Nieuwenhuijzen Kruseman, 1987) have been reported. In pedigree 5 , the younger affected male was examined at age 6 and reported (Khairi et al., 1975) to have no mucosal neuromas and normal catecholamines in plasma and urine. Although his mother had noticed in infancy the characteristic lip changes that she had noted in his older sister and brother, his thyroid was not removed until age 9. On examination at age 20 he also had definite mucosal neuromas of the tongue.

\section{DNA Markers and Genotyping}

DNA was extracted from peripheral blood (Gustafson et al., 1987) and digested with restriction enzymes as recommended by the suppliers. Agarose electrophoresis was performed as described (Devilee et al., 1988), except that Tris-borate buffer replaced Tris-acetate buffer. Fragments were blotted on Nytran filters and hybridized with a probe for D10Z1 as described (Devilee $e t$ al., 1988) or with probes for the other RFLPs as described (Meinkoth and Wahl, 1984). The following DNA markers were used: p9-12A/1dIII2.5/TaqI/ (D10S5) (McDermid et al., 1987); pH4/MspI or BglII/ (RBP3) (Liou et al., 1987); p(alpha)10RP8/MspI/ (D10Z1) (Devilee et al., 1988; Wu and Kidd, 1990); p7A9/MspI or TaqI/(D10S24) (Wu et al., 1988); pMCK2/RsaI or MspI/(D10S15) (Lathrop et al., 1988); pGEM1-P32/KpnI,BanII,HinfI/(FNRB) (Wu et al., 1989); and $\mathrm{pB} / \mathrm{R} 2 / \mathrm{MspI} /(\mathrm{FNRB})$ (Goodfellow et al., 1989).

\section{Linkage Analysis}

Linkage analysis was performed with the LINKAGE program package version 5.0 (Lathrop et al., 1984) run on an IBM PS/2 Model $50 Z$ computer with DOS version 3.30. The RFLP contribution of missing individuals relevant to analysis of linkage to MEN2B could not be inferred from the genotypes of the offspring or parents without reference to population allele frequencies in four instances (deceased spouse in pedigree 5, at D10S5; the mother in pedigree 12 at D10S15; the father in pedigree 13 at D10S15; the mother in pedigree 14 at D10S15). For analysis of these pedigrees the population frequency of the TaqI RFLP at D10S5 was from Simpson et al. (1987), and the frequencies of three alleles at the D10S15 RFLP with either $R s a \mathrm{I}$ or $M s p \mathrm{I}$ were $0.79,0.12$, and 0.09 . The frequency used for the MEN2B gene was 0.0001 , and the mutation rate assumed at this locus was 0.00001 . The fraction of MEN2B carriers manifesting any aspect of the syndrome was assumed to be $80 \%$ between birth and age 5 and $99 \%$ over age 5 . The rarity of MEN2B has prevented observations that would provide estimates of age-of-onset of the accuracy available in MEN2A provided by Gagel et al. (1982). For multipoint analysis the distances between loci used were from Wu et al. (1990). Because the multipoint analysis of all the pedigrees exceeded the capacity of our computer, pedigrees 1-10 (Fig. 1) were analyzed as one group, and pedigrees $11-14$ were analyzed as a second group. The lod scores from the two groups were added at each recombination fraction.

\section{RESULTS}

Table 1 shows the results of analysis of linkage between MEN2B and DNA markers. These pairwise results indicate that MEN2B is linked to D10Z1 (with a lod score of 5.42 at $\theta=0.02$ and a 1-lod confidence interval of $0-0.13$ ) but is not closely linked to D10S24 on the short arm. The results are only slightly positive for linkage to RBP3 but strongly positive for linkage to D10S15 (which is tightly linked to RBP3) because RBP3 was informative for a probable recombinant with MEN2B but not informative in several other off- 
TABLE 1

Pairwise Linkage of MEN2B to Chromosome 10 Markers

\begin{tabular}{lrrrrrrrrr}
\hline & \multicolumn{1}{c}{$\theta_{\mathrm{m}}=\theta_{f}$} \\
\cline { 2 - 8 } & \multicolumn{1}{c}{0} & 0.001 & 0.05 & 0.1 & 0.2 & 0.3 & 0.4 & $\hat{\theta}$ & Lod at $\hat{\theta}$ \\
\hline D10S24 & -7.57 & -5.16 & -1.06 & -0.39 & 0.06 & 0.11 & 0.04 & 0.28 & 0.12 \\
FNRB & 1.63 & 1.67 & 2.06 & 1.96 & 1.51 & 0.93 & 0.37 & 0.05 & 2.06 \\
D10Z1 & 5.22 & 5.25 & 5.29 & 4.83 & 3.60 & 2.23 & 0.93 & 0.02 & 5.42 \\
RBP3 & -1.51 & 0.17 & 1.50 & 1.44 & 0.99 & 0.47 & 0.09 & 0.06 & 1.51 \\
D10S15(MCK2) & 0.63 & 2.58 & 3.74 & 3.48 & 2.63 & 1.67 & 0.74 & 0.04 & 3.75 \\
D10S5 & -1.95 & -0.02 & 1.13 & 1.13 & 0.83 & 0.44 & 0.44 & 0.07 & 1.16 \\
\hline
\end{tabular}

spring in whom D10S15 was informative. Because no DNA marker was informative in every kindred, we used multipoint linkage analysis to combine results on one map (Fig. 2) which shows the peak lod score of 7.12 at the midpoint between D10Z1 and RBP3. Our results with MEN2B compared with a multipoint map of MEN2A (Wu et al., 1990) show overlapping confidence limits. The 1-lod confidence interval for MEN2B extends from D10Z1 $9 \mathrm{cM}$ on the $q$ arm to 6 $\mathrm{cM}$ on the $\mathrm{p}$ arm in the female map. The most likely gene order FNRB-D10Z1-MEN2B was 27 times more likely than MEN2B-FNRB-D10Z1 and $3 \frac{1}{2}$ times more likely than FNRB-MEN2B-D10Z1. Additional data will be required to establish the order of these loci with confidence.

A possible crossover in pedigree 2 between MEN2B and both D10Z1 and FNRB provides evidence that MEN2B lies on the long arm flanked by D10Z1 and RBP3/MCK2. This involved an unaffected $8 \frac{1}{2}$-yearold male who shows none of the phenotypic features of MEN2B which his mother and two brothers mani-

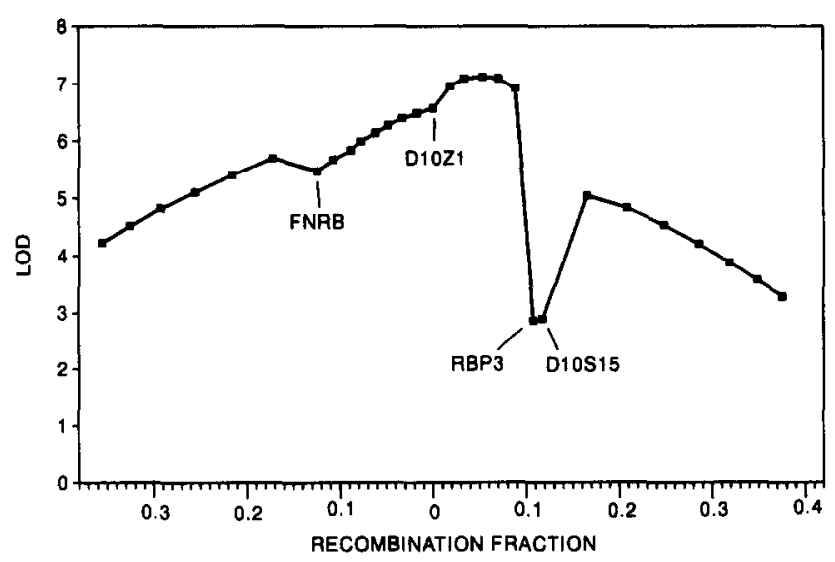

FIG. 2. Multipoint analysis of MEN2B using the LINKMAP program version 5.02. A constant female:male genetic distance ratio of 10:1 was assumed (30) and the results are presented using female recombination fractions. D10Z1 was arbitrarily set at 0 , FNRB at 0.124, RBP3 at 0.108 , and MCK2 at 0.118 on the female map (30). fested at a much earlier age. Additionally, strong evidence for his unaffected status is provided by a recent unequivocally negative pentagastrin-stimulated calcitonin test for MTC. This result effectively excludes MTC, which is present and often metastatic in MEN2B patients by age 4 (Jones and Sisson, 1983). A single crossover between RBP3, D10S15, and D10S5 on one side and MEN2B, D10Z1, FNRB, and D10S24 on the other side probably occurred in pedigree 1 (Fig. 1). This resulted in different DNA marker types in two people who have MEN2B and thus is unlikely to be an artifact of misclassification of MEN2B genotype. In both of these possible crossovers the phase in the affected parent is unknown, so the lod scores for linkage at the marker are not strongly negative. The locations of the probes used are shown on the physical map of chromosome 10 (Fig. 3) modified from Smith and Simpson (1989).

\section{DISCUSSION}

Although our initial linkage studies with MEN2B (Jackson et al., 1988) were only suggestive of linkage to the centromere marker D10Z1 (lod score of 2.68 at $\theta$ $=0$ ), limited data on linkage to the same markers to which MEN2A had been linked were available then. No other reports of linkage analysis of MEN2B have appeared. Wu et al. (1990) have recently reported evidence for linkage between MEN2A and D10Z1 (lod score of 12.0 at $\theta=0$ ). The data reported here confirm that MEN2B, like hereditary medullary thyroid cancer without pheochromocytoma (Sobol et al., $1989 \mathrm{~b}$ ), is closely linked to the same DNA markers near the centromere of chromosome 10 to which MEN2A has been linked and suggest a close relationship of the similar syndromes but do not establish allelism of the genes.

This study illustrates well the dependence of gene localization on the accurate identification of affected individuals on the basis of clinical data. If the crossover male in pedigree 2 (Fig. 1 ) is correctly identified as not having the disease gene, MEN2B is likely local- 


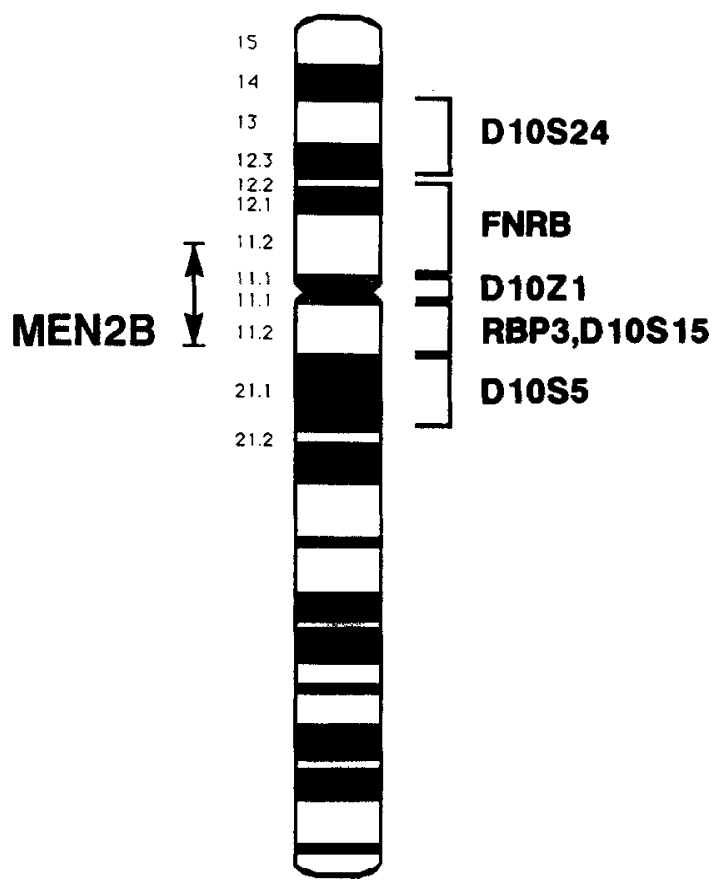

FIG. 3. Physical map of chromosome 10 modified from Smith and Simpson (25) to illustrate the location of markers utilized in this study and indicating the most likely location for MEN2B.

ized to the proximal long arm of chromosome 10 by studies of this one family. Although our clinical experience has shown that the diagnosis of MEN2B can be made in early childhood by observation of the mucosal neuromas by experienced parents and/or physicians and by conversion of negative to positive pentagastrin-stimulated calcitonin testing for the thyroid cancer by age 5 , insufficient data on this rare disease are available at present to exclude all doubt.

Although these findings are compatible with the contiguous gene theory for tumors of the syndromes (Jackson et al., 1989; Jackson and Norum 1989), further evidence of the nature of the actual genes involved is needed. The evidence for the genes for MEN $2 \mathrm{~A}$ and MEN 2B being located close to each other would suggest that MEN $2 B$ is probably a better term for the mucosal neuroma phenotype than the MEN 3 terminology suggested by Khairi et al. (1975), even though that terminology did emphasize that they were separate genetic entities. These findings suggest that studies of the gene for either MEN 2 syndrome may contribute knowledge of the gene for the other syndrome.

\section{ACKNOWLEDGMENTS}

This work was sponsored in part by the Dykstra Foundation, by the Comite departemental de l'Ain of the Ligue Nationale Francaise contre le Cancer, and by National Institutes of Health Grant
HG00107 to H.F.W. Access to the various kindreds was provided by M. R. A. Khairi, Indianapolis; D. Wilhelm, Port Huron, MI; J. D. Fachinie and G. B. Talpos, Henry Ford Hospital; J. L. Tummala, Flint, MI; Dr. G. W. Sizemore, Evanston, IL; S. Shalet, Manchester, England; R. N. Schimke, Kansas City, KS; C. Chateauneuf, Toulouse, France; and H. C. N. Kruseman, Maastricht, The Netherlands. Some DNA analyses were performed by S. A. Narod, Lyon, France, and by S. E. Mole and C. G. P. Mathew of Cambridge, England. The clone pH4(RBP3) was kindly provided by C. D. B. Bridges, p9-12A/1dIII2.5(D10S5) by N. E. Simpson, pMCK2(D10S15) by Y. Nakamura, p7A9(D10S24) by W. K. Cavenee, pGEM1-P32(FNRB) by W. S. Argraves and E. Ruoslahti, and $\mathrm{pB} / \mathrm{R} 2$ (FNRB) by P. J. Goodfellow. Calcitonin assays on members of the MEN2B families were kindly performed by A. $H$. Tashjian, Jr., Boston. D. I. Smith, Detroit, provided training in marker typing. J. Ott, New York, NY, kindly provided the LINKAGE program package. Expert technical assistance was provided by P. L. Christopherson, D. K. Noffze, and K. R. Zubrickas of the Genetics Research Laboratory, Henry Ford Hospital, Detroit, MI.

\section{REKERENCES}

1. Carney, J. A., Sizemore, G. W., and Lovestedt, S. A. (1976). Mucosal ganglioneuromatosis, medullary thyroid carcinoma, and pheochromocytoma: Multiple endocrine neoplasia, type 2B. Oral Surg. 4: 739-752.

2. Devilee, P., Kievits, T., Waye, J. S., Pearson, P. L., and WILLARD, H. F. (1988). Chromosome-specific alpha satellite DNA: Isolation and mapping of a polymorphic alphoid repeat from human chromosome 10 . Genomics 3: 1-7.

3. Eyer, S. D., Snover, D. C., AND Delaney, J. P. (1988). Diverticulitis in the multiple endocrine neoplasia type IIB syndrome. Amer. J. Gastroenterol. 83: 183-186.

4. Gagel, R. F., Jackson, C. E., Block, M. A., Feldman, Z. T., Reichlin, S., Hamiton, B. P., and TashJian, A. H., JR. (1982). Age-related probability of development of hereditary medullary thyroid carcinoma. J. Pediatr. 101: 941-946.

5. Goodfellow, P. J., Nevanlinna, H. A., Gorman, P., Sheer, D., LAM, G., AND Goodfellow, P. N. (1989). Assignment of the gene encoding of the beta subunit of the human fibronectin receptor (beta-FNR) to chromosome 10p11.2 Ann. Hum. Genet. 53: 15-22.

6. GoRlin, R. J., AND MIRkIN, B. L. (1972). Multiple mucosal neuromas, pheochromocytoma, medullary carcinoma of the thyroid and marfanoid body build with muscle wasting: Syndrome of hyperplasia and neoplasia of neural crest derivatives; and unitarian concept. $Z$. Kinderheikld 113: 313-325.

7. Gustafson, S., Proper, J. A., Bowier, E. J. W., AND Somer, S. S. (1987). Parameters affecting the yield of DNA from human blood. Anal. Biochem. 165: 294-299.

8. Jackson, C. E., Talpos, G. B., Block, M. A., Norum, R. A., LLOYd, R. V., AND TASHJIAN, A. H., JR. (1984). Clinical value of tumor doubling estimations in multiple endocrine neoplasia type II (MEN-II). Surgery 96: 981-986.

9. Jackson, C. E., Norum, R. A., O'Neal, L. W., Nikolai, T. F., AND DELANEY, J. P. (1988). Linkage between $M E N 2 B$ and chromosome 10 markers linked to MEN2A. Amer. J. Hum. Genet. 43: A154.

10. Jackson, C. E., Van Dyke, D. L., Talpos, G. B., Norum, R. A., AND TASHJIAN, A. H., JR. (1989). MEN-2 tumor associations suggest a linear order of specific endocrine tumor genes. Horm. Metab. Res. Suppl. 21: 9-12.

11. JACKson, C. E., AND Norum, R. A. (1989). Genetic mechanisms of neoplasia in MEN 2. Henry Ford Hosp. Med. J. 37: $109-111$. 
12. Jones, B. A., AND Sisson, J. C. (1983). Early diagnosis and thyroidectomy in multiple endocrine neoplasia type 2 b. J. Pediatr. 102: 219-233.

13. Khatri, M. R. A., Dexter, R. N., Burzynski, N. J., AND Johnston, C. C., JR. (1975). Mucosal neuroma, pheochromocytoma and medullary thyroid carcinoma: Multiple endocrine neoplasia type 3. Medicine (Baltimore) 54: 89-112.

14. Kullberg, B. J., and Niruwenhuluzen Kruseman, A. C. (1987). Multiple endocrine neoplasia type $2 b$ with a good prognosis. Arch. Intern. Med. 147: 1125-1127.

15. Lathrop, G. M., Lalouel, J.-M., Julier, C., and OTT, J. (1984). Strategies for multilocus linkage analysis in human. Proc. Natl. Acad. Sci. USA 81: 3443-3446.

16. Lathrop, G. M., Nakamura, Y., Cartwright, P., O'ConNell, P., Leppert, M., Jones, C., TAteishi, H., Poragg, T., LALOUEL, J.-M., AND WHITE, R. (1988). A primary genetic map of markers for human chromosome 10 . Genomics 2: 157164.

17. Liou, G. I., Li, Y., WANG, C., Fong, S.-L., Bhattacharya, S., AND BRIDGES, C. D. B. (1987). BglII RFLP recognized by a human IRBP cDNA localized to chromosome 10. Nucleic Acids Res. 15: 3196.

18. Mathew, C. G. P., Chin, K. S., Easton, D. F., Thorpe, K., Carter, C., Liou, G. I., Fong, S-L., Bridges, C. D. B., HaAk, H., Kruseman, A. C. N., Schifter, S., Hansen, H. H., 'TElenius, H., Telenius-Berg, M., ANd Ponder, B. A. J, (1987). A linked genetic marker for multiple endocrine neoplasia type 2A on chromosome 10. Nature (London) 328: 527-528.

19. McDermid, H. E., Goodfellow, P. J., Duncan, A. M. V., Brasch, K. R., Simpson, N. E., Souza, C. D., Holden, J. J. A., AND WhITE, B. N. (1987). A polymorphic locus, D10S5, at 10q21.1. Nucleic Acids Res. 15: 5498.

20. MeINKoth, J., AND W AHL, G. (1984). Hybridization of nucleic acids immobilized on solid supports. Anal. Biochem. 138: 267-284.

21. Nakamura, Y., Lathrop, M., BragG, T., Leppert, M., O'Connell, P., Jones, C., LALOUEL, J.-M., AND Whitk, R. (1988). An extended genetic linkage map of markers for human chromosome 10. Genomics 3: 389-392.

22. Nakamura, Y., Mathew, C. G. P., Sobol, H., Easton, D. F., Telenius, H., Bragg, T., Chin, K., Clark, J., Jones, C., Lenoir, G. M., WhITE, R., AND PoNDER, B. A. J. (1989). Linked markers flanking the gene for multiple endocrine neoplasia type 2A. Genomics 5: 199-203.

23. O'NEAL, L. W. (1983). Multiple endocrine neoplasia, type IIb: Medullary carcinoma of the thyroid, pheochromocytomas, neuromas, and ganglioneuromatosis. Res. Medica 1: 7-16.

24. Simpson, N. E., Kidd, K. K., Goodfellow, P. J., MCDERmid,
H., Myers, S., KIDD, J. R., JACKSON, C. E., DuncaN, A. M. V., Farrer, L. A., Brasch, K., Castiglione, C., Genet, M., Gertner, J., Greenberg, C. R., Gusella, J. F., Holden, J. J. A., AND WHITE, B. N. (1987). Assignment of multiple endocrine neoplasia type $2 \mathrm{~A}$ to chromosome 10 by linkage. Nature (London) 328: 528-530.

25. Smith, M., ANd Simpson, N. E. (1989). Report of the committee on the genetic constitution of chromosomes 9 and 10. $C y$ togenet. Cell Genet. 51: 208.

26. Sobol, H., Salvetti, A., Bonnardel, C., ANd Lenoir, G. M. (1988). Screening multiple endocrine neoplasia type 2A families using DNA markers. Lancet 1: 62-63.

27. Sobol, H., Narod, S. A., NaKamura, Y., Boneu, A., et al. (1989a). Screening for multiple endocrine neoplasia type $2 a$ with DNA-polymorphism analysis. $N$. Engl. J. Med. 321: 996-1001.

28. Sobol, H., Narod, S. A., Schuffenecker, I., Amos, C., et al. (1989b). Hereditary medullary thyroid carcinoma: Genetic analysis of three related syndromes. Henry Ford Hosp. Med. J. 37; 116-119.

29. Williams, E. D., AND Pollock, D. J. (1966). Multiple mucosal neuromata with endocrine tumours: A syndrome allied to von Recklinghausen's disease. J. Pathol. Bacteriol. 91: 71-80.

30. Wu, J., Carson, N. L., Myers, S., Pakstis, A. J., KIDD, J. R., Castiglione, C. M., Anderson, L., Hoyle, L. S., Genel, M., VERDY, M., JACKSON, C. E., Simpson, N. E., AND KidD, K. K. (1990). The genetic defect in multiple endocrine neoplasia type 2A maps next to the centromere of chromosome 10. Amer. J. Hum. Genet. 46: 624-630.

31. Wu, J., CAVENEe, W. K., MikI, T., AND KidD, K. K. (1988). A polymorphic DNA marker on chromosome 10 linked to RBP3 on the MEN2A side. Cytogenet. Cell Genet. 48: 246-247.

32. Wu, J., Giufrra, L. A., Goodfellow, P. J., Myers, S., CarSON, N. L., Anderson, L., Hoyle, L. S., Simpson, N. E., AND KIDD, K. K. (1989). The beta subunit locus of the human fibronectin receptor: DNA restriction fragment length polymorphism and linkage mapping studies. Hum. Genet. 83: 383-390.

33. WU, K., AND KIDD, K. K. (1990). Extensive sequence polymorphisms associated with chromosome 10 alpha satellite DNA and its close linkage to markers from the pericentromeric region. Hum. Genet. 84: 279-282.

34. WYMAN, A. R., AND WHITE, R. (1980). A highly polymorphic locus in human DNA. Proc. Natl. Acad. Sci. USA 77: 67546758.

35. Yamamoto, M., TakaI, S., Miki, T., Motomura, K., OKazaka, M., Nishisho, I., Tateishi, H., Honjo, T., Pakstis, A. J., AND MORI, T. (1989). Close linkage of MEN2A with RBP3 locus in Japanese kindreds. Hum. Genet. 82: 287-288. 